\title{
Development of learning materials reading understanding using CIRC in four primary schools
}

\author{
Weni Aulia', Ardipal², Darnis Arief ${ }^{3}$ \\ ${ }^{123}$ Universitas Negeri Padang, Padang - Indonesia, (weniaulia93@gmail.com)
}

\begin{abstract}
This research is motivated by teaching materials that are used less interest of students to read and not yet contain reading stage (pre-reading, reading and post-reading). The purpose of developing this instructional material is to produce a reading material that is valid, practical, and effective. The type of this research is development research using 4$\mathrm{D}$ model. Based on the validity test obtained percentage of RPP by the expert validator $91.6 \%$ and $90.0 \%$ practitioner validator. Percentage of teaching materials by $90.6 \%$ expert validator and $89.9 \%$ practitioner validator. Practicality test of the implementation of RPP obtained percentage of $92.7 \%$. Assessment of teacher responses obtained $93 \%$ and assessment of the response learners obtained $89.2 \%$ percentage The effectiveness of learning tools learners obtained percentage $81.6 \%$. Assessment of comprehension reading process obtained $75.5 \%$ percentage. Based on these results, learning materials to read the understanding using the CIRC model can already be declared valid, practical, and effective.
\end{abstract}

Keywords: learning materials, reading comprehension CIRC

\section{Introduction}

Reading has a very important role in an effort to develop the intelligence of learners, without having the skills to read, learners will have difficulty in understanding learning. Much of the research on reading skills is like in Malaysia (Javed, lin siew eng, abdul, mohamed, semry, and maniam2015), Singapore (Gonzales, 2016), Fhilipina (Patrisha, 2016), Indonesia (Bambang, 2014), Iran (Hamidavi , Mansoureh, Gorjian, 2016), Turkey (Gurses, 2016), Australia (Bouvet, 2016). Japanese (Khaki, 2014) and China (jiang, 2015) but also on other learning, since all learning basically emphasizes the effort of understanding from a reading. The process of reading learning is not the only purpose of reading learning, but by doing the right process will affect the acquisition of results and understanding after reading.

According to Nurhadi (2016: 2) reading is a process of reading reading in a critical, creative way that readers do to gain a thorough understanding of the reading, followed by an assessment of the circumstances, values, functions, and impacts of the reading. All reading learning process will certainly work properly if coupled with the appropriate teaching materials. A learning can not be separated from the source of learning, the role of teachers is very important because it should be the 
teacher who makes the teaching materials. Teachers should be able to create and develop their own teaching materials so that the learning process can be in accordance with the expected.

Teaching materials used in the learning process are all forms used to assist teachers in carrying out teaching and learning activities. According Sagala (2009: 23) one of the competencies of professionalism that must be owned by the teacher is able to arrange quality teaching materials in accordance with competence, basic competence, and teaching materials in accordance with the needs and characteristics of learners. Teaching materials aims to assist learners in learning something, providing various types of teaching materials, facilitating teachers in the implementation of learning, and make the activities learning becomes more interesting (Hamdani, 2011: 122).

Depdiknas (2008: 6) teaching materials serve as, first, guidelines for teachers who will direct all activities in the learning process, as well as the substance of competence that should be taught to learners, secondly, guidelines for learners who will direct all activities in the process learning and is the substance of competence that must be mastered, and third, as a means of evaluating the achievement of learning outcomes. From the opinion of the experts above, it can be concluded that the good teaching materials and ideal it is teaching materials in accordance with applicable competencies and in accordance with the needs and characteristics of learners to achieve the results of learning that is evective.

Based on the preliminary study that the authors do to the teaching materials of students SD Negeri Batu Bulek, visible educators who are still using conventional materials, the teaching materials live wear, live, instant, and without the effort to plan, prepare, and arrange their own, creativity and understanding of teachers on the design of teaching materials is also still lacking, teaching materials used by teachers not in accordance with the stages of reading, namely pre-reading, reading and postreading, teach only use one color so it is less appropriate with the characteristics of learners whose age likes bright colors and interesting pictures.

Based on these problems required the development of teaching materials by using the right model for reading comprehension skills. One of the right alternatives to developing learning comprehension reading materials is to use the CIRC model as it is in line with the characteristics of fourth grade students. Therefore, the authors are interested in developing an Instructional Learning Material of Understanding using CIRC model that has the potential to be developed as teaching materials in IV Elementary School because it has advantages, among others, first, can create a fun learning atmosphere because students are grouped in heterogeneous groups and secondly, improve cooperation among learners because students are given the opportunity to discuss each other (Istarani (2012: 113).

Based on the background and limitations of the issues raised, then the formulation of the problem in this study are described as follows. (1) How does the validity of teaching materials read comprehension using learning with the Cooperative Integrated Reading And Composition (CIRC) model in Grade IV Primary School? (2)How does the practice of teaching materials read understanding using learning models with Cooperative Integrated Reading and Composition (CIRC) in Grade IV Primary School? (3) How is the effectiveness of reading comprehension materials using Cooperative Integrated Reading and Composition (CIRC) based learning in Grade IV Primary School? 


\section{Methods}

This type of research is research development (Research and Development). According to Borg \& Gall (in Setyosari, 2010: 263) the educational research and development model itself is based on an industry-based model of development, whose findings are used to design products and procedures, which are then systematically field tested, evaluated, meet certain criteria of effectiveness, quality, and standards. The development model used in this study refers to the 4-D model, according to Sugiyono (2008: 404) stages of 4-D model, among others: define, design, development and disseminate ).

On define stage, curriculum analysis, requirement analysis, and learner analysis are performed. The result of this analysis will be used as a foundation to design a teaching materials. The design of teaching materials includes all components of teaching materials according to DEPDIKNAS consist of: (1) cover, (2) introduction, (3) table of contents, (4) user guide, (5) SK and KD to be achieved, (6), (7) goals to be achieved, (8) tasks or activities, (9) supporting information, and (10) bibliography.

This research was conducted at SDN 05 Batu Bulek in the even semester of academic year 2017/2018 which was held on January 2, 2018 for 3 times meeting with the number of students 21 people. The product distribution stage is done at SDN 09 Batu Bulek and SDN 27 Batu Bulek with the number of students is 12 and 11 people.

\section{Results and Discussion}

The results of research on developing the teaching materials to write narrative using graphic organizer story map can be seen from the level of validity, practicality, and effectiveness.

\section{Validity}

The purpose of the validity of teaching materials is to determine the functioning of a product based on the content, language, presentation and kegrajikaan. The main parts that are validated are the suitability of KD, the indicator, the truth of the concept, and the language used. Validation is said to be complete, if the validator declare valid to the teaching materials, so it is ready for trial.

Based on the validity test, the average RPP averages $90.8 \%$ (highly valid) from expert validators, and practitioner validators. The result of the average percentage of teaching materials was $89.5 \%$ (very valid) from expert validators, and practitioner validators. Practical test results from the implementation of RPP as a whole is obtained with a percentage of $92.7 \%$ (very practical). Assessment of teacher response $93 \%$ and assessment of the learners $89.2 \%$. Effectiveness seen from the activities of learners overall percentage obtained $81.6 \%$ with very good category. From the assessment of reading comprehension process obtained $75.5 \%$ with high category. From the assessment The results of reading comprehension obtained by $82.4 \%$ percentage with very high category. From the assessment of the results of reading the understanding is known that the percentage of mastery reading comprehension increases. Based on these results, it was concluded that learning materials reading comprehension using the CIRC model developed can be declared valid, practical, and effective. For more details, can be described as follows:

\section{Practicality}

After the validation process with the experts is completed, a trial is done to see the practicality of the teaching materials. Trial conducted as many as 3 times meeting. During the trial, the study was 
observed by 2 observers. After the validation process with the experts completed, we conduct a test to see the practicality of the teaching materials. Tests conducted on three meeting. During the trial, the study was monitored by two observers. Based on the test, we found that teaching materials reading comrehensions with CIRC meet the practical criteria. The practicality of teaching materials on reading comprehensions using CIRC for $4^{\text {th }}$ grade in Elementary School as a whole in very practical category. Based on the observation of the implementation of RPP earn 92,7\% for very practical category. The result of questionnaire of teacher response obtained $93 \%$ percentage for very practical category, and student response assessment $89,2 \%$ for very practical category. This result provides an illustration that the teaching materials on reading comprehensions using CIRC for $4^{\text {th }}$ grade in Elementary School is very practical and can assist in implementing the reading comprehensions learning process.

\section{Effectiveness of teaching materials}

The effectiveness of instructional materials can be seen through the assessment of the activities and results of reading skills of learners. For more details the effectiveness of teaching materials can be described as follows. The effectiveness of teaching materials can be observed through the assessment of student activities, assessment of reading comprehensions process, and the result of reading comprehensions skills. The assessment results of student activity obtained $81,6 \%$ with very good categories. Then the assessment of the reading comprehensions process obtained $75,5 \%$ with high category, and the assessment of reading comprehensions skill obtained $82,4 \%$. The observation of students' activity, process assessment, and assessment result of reading comprehensions of students give a very good picture. The results of research for more details can be seen in the following tables and diagrams.

Table 1.1 Recapitulation of Teaching Materials Assesment

\begin{tabular}{|l|l|l|c|c|}
\hline No. & Aspect & Result & Category \\
\hline \multirow{2}{*}{1.} & Validity & Content & $93,3 \%$ & Very valid \\
\cline { 3 - 5 } & & Language & $86,6 \%$ & Very valid \\
\cline { 3 - 5 } & & Graffiti & $88,6 \%$ & Very valid \\
\hline \multirow{2}{*}{2.} & \multirow{2}{*}{ Practicality } & presentation & $89,5 \%$ & Very Valid \\
\cline { 3 - 5 } & & RPP implementation & $92,7 \%$ & Very simple \\
\cline { 3 - 5 } & & Teachers response & $93 \%$ & Very simple \\
\cline { 3 - 5 } & & Students response & $89,2 \%$ & Very simple \\
\hline \multirow{2}{*}{3.} & \multirow{2}{*}{ Effectiveness } & Student activities & $81,6 \%$ & Very high \\
\cline { 3 - 5 } & & Students reading process & $75,5 \%$ & high \\
\cline { 3 - 5 } & & Student reading result & $82,4 \%$ & Very high \\
\hline
\end{tabular}




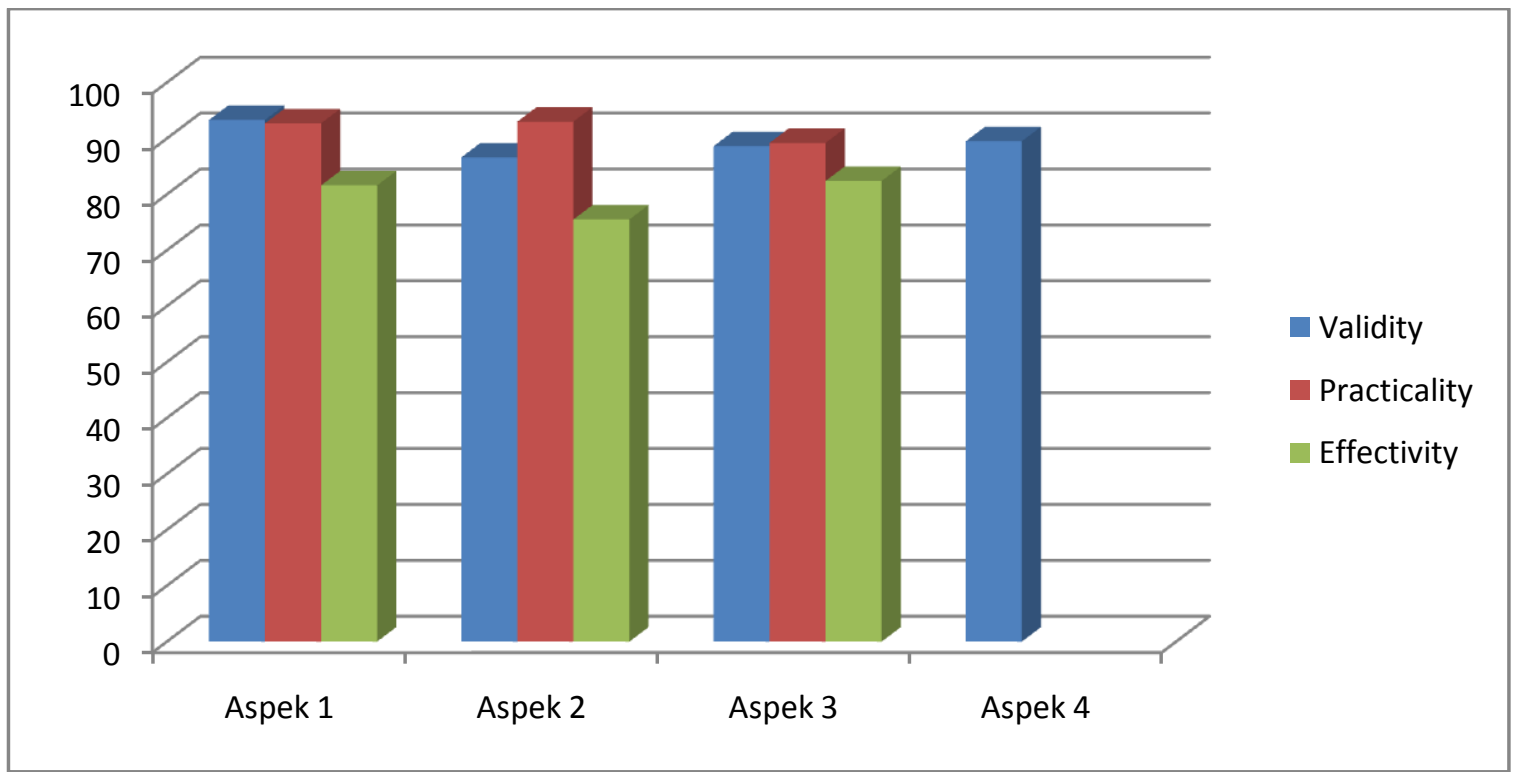

Picture 1.1 Recapitulation of Teaching Materials Assesment

\begin{tabular}{|c|c|c|c|}
\hline \multicolumn{4}{|c|}{ Description } \\
\hline & Validity & Practicality & Effectivity \\
\hline Aspect 1 & Content & RPP Implementation & Students activities \\
\hline Aspect 2 & Language & Teachers response & Students writing process \\
\hline Aspect 3 & Graffiti & Students response & Students writing results \\
\hline Aspek 4 & Presentation & - & - \\
\hline
\end{tabular}

\section{Conclusion}

Based on the development and experiments that have been conducted on learning materials to read the understanding by using the CIRC model in the fourth grade of elementary school, the following conclusions are obtained.

1. The validity of teaching materials read comprehension with Comics using CIRC in grade IV of elementaryschool It has been produced reading comprehension material using CIRC model in Class IV SD with very valid category. This can be seen based on the validation of learning materials reading comprehension using CIRC model by validator that has been implemented. These results illustrate that the developed teaching material has been valid and can be used in the learning process.

2. Practicality of teaching materials reading comprehension using CIR model in grade IV of elementary school Practicality of teaching materials reading comprehension using the CIRC model in grade IV primary school in the category is very practical. This is derived from the observation of the implementation of RPP on teachers who teach, teacher response, student response, observation sheet, and interview guidelines use of teaching materials. These results provide an illustration that teaching materials are very practical and can help in implementing the process of reading comprehension learning

3. The Effectiveness of Learning Materials Reading Understanding by using CIRC model in Grade IV Primary School. The effectiveness of teaching materials reading comprehension 
using the CIRC model in the fourth grade of elementary school can be known through the activities of learners, process assessment, and assessment of reading comprehension results of learners. Student activity is considered very good because of observations by obsever that learners have no difficulty in carrying out the learning process and can follow it well, both in trial school and in implementation school.

\section{References}

Depdiknas. ( 2006). Panduan Penyusunan Kurikulum Tingkat Satuan Pendidikan. Jakarta: Depdiknas.

Depdiknas .( 2009). Pengembangan Bahan Ajar. Jakarta: Diklat Bimtek/KTSP.

Durukan. E. ( 2011). Effects of cooperative integrated reading and composition (CIRC) technique on reading-writing skills. Department of Turkish Education, Faculty of Fatih Education, Black Sea Technical University, Turkey.

Gupta \& Ahuja. (2014). Cooperative integrated reading composition (circ): impact on Reading comprehension achievement in english among Seventh graders. Impact Journals

Gurses. G.O. (2016). Investigating reading comprehension and learning styles in relation to reading strategies in L2. Volume 28, No. 1 ISSN $1539-0578$ pp. 20-42

Hamidavi.N., Mansoureh, A.S., \& Gorjian.B. (2016). The Effect of Clil Method TeachingReading Comprehension to Junior High School Students. Bulletin de la Société Royale des Sciences de Liège, Vol. 85, 2016, p. $1642-1652$

Hamdani. (2011) . Strategi Belajar Mengajar. Bandung: Pustaka Setia

Istarani.(2012). 58 Model Pembelajaran Inovatif. Medan : Media Persada

Jiang,Yan. ( 2015). Chinese College Students' English Reading Comprehension in Silent and Loud Reading-Mode. English Language Teaching; Vol. 8, No. 4; 2015 ISSN 19164742 E-ISSN 1916-4750 Published by Canadian Center of Science and Education

Javed.M., Lin Siew Eng, \& Mohamed.A.R.(2015). Developing Reading Comprehension Modules to FacilitateReadingComprehension Among Malaysian Secondary School ESL Students. E-ISSN. 1308-1470

Khaki.N. (2014). Improving Reading Comprehension in a Foreign Language: Strategic Reader. Volume 14, Number 2.

Nurhadi.( 2016). Teknik Membaca. Jakarta: Bumi Aksara

Pan.C.Y \& Wu.H.Y. ( 2013). The Cooperative Learning Effects on English Reading Comprehension and Learning Motivation of EFL Freshmen. EnglishLanguage Teaching; Vol. 6, No. 5; 2013 .ISSN 1916-4742 E-ISSN 1916- 4750 Published by \Canadian Center of Science and Education

Saddhono, K \& St.Y.Slamet. (2012). Meningkatkan Keterampilan Berbahasa Indonesia (Teori \& Aplikasi Bandung: Karya Putra Darwati

Zare.P. (2013) . The Relationship between Reading Comprehension and Reading Strategy Use Among Malaysian ESL Learners. Department of Language and Humanities Education Faculty of Educational Studies Universiti Putra Malaysia 43400 Serdang, \Selangor, Malaysia 